DOI https://doi.org/10.36059/978-966-397-113-1/196-218

\title{
THE PATIENT'S RIGHTS TO PROPHYLACTIC MEASURES
}

\section{Klimenko O. V.}

According to the official statistics of the Ministry of Health of Ukraine, there is a difficult situation with the state of population's health in the country, the main indicators of which such as an average life expectancy, mortality and illness level, are far from optimistic and have a tendency to deteriorate in the recent years.

Insufficient financing does not allow the Ukrainian budget medicine to provide the population with a necessary level of medical care, including prophylactic measures.

The purpose of the study is to identify the actual state of the patient's rights to prophylactic measures with the goal of reforming a health care system in a modern Ukraine.

Before defining the concept of «the patient's right to prophylactic measures», it is important to find out what prophylactic measures and patient are as well as the rights of people to prophylactic measures in the field of medical health care.

Thus, prophylactic measures are an essential component of the health care system, which is mainly aimed at forming the social-medical activities and motivating people to maintain a healthy lifestyle.

These measures are enshrined in the Article 6 of the Law of Ukraine "The Fundamentals of Ukrainian Law on Health Care", which states that every citizen has the right to health care, which includes:

a) Living standards, including food, clothing, accommodation, medical care and social services and welfare which are necessary for supporting human health;

b) Safe environment for life and health;

c) Sanitary and epidemic well-being of the territory and community, where a person lives;

d) Safe and healthy working, studying, domestic and resting conditions.

All of the examples mentioned above are the examples of citizen's rights to general prophylactic measures in the field of health care. If we 
are talking about the patient's right to prophylactic measures, it is important to define who the patient is.

Patients (from Latin patiens - those who bear, suffer) - is a person or any living creature, who obtains medical assistance, is under medical observation and/or receives treatment for any illness, pathological condition or any disorder of health and life-sustaining activities, as well as uses medical services regardless the presence of the disease.

Accordingly the patient's right to prophylactic measures involves only those measures related to indirect references of people to the medical assistance or services. The basic medical prophylactic measures are medical examination, vaccination and rehabilitation.

Medical examination is an active dynamic monitoring of the population's health state, which includes a complex of prophylactic, diagnostic and medical-treatment methods.

Initially, the principles and methods of medical examination were used to fight socially-dangerous diseases like tuberculosis, syphilis, trachoma and etc. Nowadays the medical examination method is being used to monitor pregnant women, children, employees in the leading industrial and agronomic production, and patients with chronic diseases.

The main goal of medical examination is to protect and strengthen the population's health, prevention of diseases, the reduction of disease incidence, disabilities, mortality and achieving high life expectancy. Medical examination is included as a component in the large system of disease prevention, implemented by the state and the society.

Medical examination includes: a yearly medical examination with a laboratory-instrumental research to detect illnesses on early phases, as well as the examination of individuals who tend to have risks of certain illnesses development; additional examination of those, who are in need of it using modern diagnostic methods; identification of every person's health state; realization of medical-treatment set of measures to help patients and people with risk indicators and further systematic observation of their health state.

Approximately such a scheme of yearly medical examination of examination groups with the indication of nosological forms, the frequency of examinations, doctors of multiple specializations, recommended laboratory researches, and medical-treatment methods as 
well as criteria of the effectiveness of medical examinations existed in the USSR.

A district pediatrician examined all children of his/her district every year: the frequency of children examinations in their first three years of life depended mainly on their age and health status when they were born. A surgeon (orthopedist), otorinolarinogist, ophthalmologist examined the children in their first year of life, from 3 to 5 years, before they entered school, in $3^{\text {rd }}, 6^{\text {th }}$ and $8^{\text {th }}$ grades, neurophatologist - in the first year of their life, before they entered school and in $8^{\text {th }}$ grade, other specialist conducted examinations only by indications. Every year the examination of teeth and oral cavity was conducted by paramedical staff followed by further sanitation of the dentist. Anthropometry, the determination of the acuity of the eyesight and hearing, tuberculosis tests, preliminary evaluation of neuropsyhic development were also conducted by the paramedical staff. Compulsory medical examinations of children and teenagers include: blood analysis, general urine analysis and the feces analysis to detect helminthes eggs, and arterial pressure measurement (from 7 years), and the X-ray of the chest (from 13 years). The pupils of 8th grade got their blood type and rhesus-factor determined.

A district therapeuist (who is the therapeuist of both territorial and industrial areas) examined all registered adult population every year. A pre-medical examination treatment was conducted, which included measuring the height and weight of the body, arterial pressure measurement, the acuity of eyesight and hearing, pheumothatchometry. Gynecological examination of women with compulsory cytology was conducted from the age of 18; electrocardiography - from 15 to 40 once every three 3 years, after the age of 40 - every year; mammography for women - once every two years after the age of 40. Fluorography of the chest plate was conducted differentially, but not less that once every three years, in case of a high level of tuberculosis incidents occurring on a particular territory - every year. This list was compulsory ${ }^{1}$.

Currently medical examination of Ukrainian population is not compulsory for the citizens; only the duty of health care agencies to create conditions so that everybody who wants to undergo a medical examination could do it; no one can force citizens to undergo it; they must be interested in undergoing a medical examination themselves and find free time to undergo it. A similar situation is with prophylactic 
vaccinations. The necessity of vaccinations should be considered as the state's responsibility to create certain conditions for vaccinations; it is not the obligation of citizens to undergo general vaccination.

The question about correlation between conducting medical examinations and the right to consent on medical intervention is still opened (Article 43 of the Fundamentals of Ukrainian Law on Health Care: the consent of an objectively informed legally-capable patient is necessary to use certain methods of diagnostic, prophylactic measures and treatment. Part 3 of Article 284 of the Civil Code of Ukraine also requires providing medical assistance for natural persons, who reached the age of 14 only with their consent).

The reducing of prophylactic activity in prophylactic treatment establishments caused a significant loss of human and material recourses. The lack of general medical examination programs influenced the supervision on health state of work-capable population and, especially, working population ${ }^{1}$.

In 2010 in Ukraine the medical exanimation can obtain a new development. The Ministry of Health of Ukraine issued the Order "On Medical Examination of Population".

When conducting a medical examination of adults the heights, weight and arterial pressure measurements, analysis of urine and feces, chest plate X-ray, mammography and the ultra-sound examination of prostate for men must become compulsory. It was decided that the district or family doctor had to plan a medical examination for all citizens living in the service area, and made a list of all who underwent medical examination.

The price of such medical was 6 billion UAH. These conditional 6 billion UAH in calculation per 30 million work-capable people meant 200 UAH ( 25 dollars) per one person. There is barely enough money to conduct urine and feces analysis. And there is nothing for mammography, ultrasonography and x-rays because these procedures have been paid procedures for a long time;

In addition, in 2011in Ukraine the reform of a health care system was started. Its first goal was to test a new, optimized model of health care under the conditions of trial projects in specially determined districts. A full-scale reform was conducted in 2013.

\footnotetext{
1 Дорофеев М. А. Совершенствование диспансеризации работающего населения в условиях модернизации здравоохранения. Дисс. канд. мед.н. - М., 2010. - С. 168.
} 
Before the reform, we had a primary link in the form of POPs (paramedic-obstetrician posts), village medical ambulatories, district hospital, ambulance stations, clinics with district doctors and specialist doctors, $\mathrm{CDH}$ (center district hospitals), city and regional hospitals and clinics, specialized hospital dispensaries and centers.

As a result of the reform, it is planned to close almost every district and regional clinics, reduce $\mathrm{CDH}$ to its minimum, leaving only emergency medical care as their main function, to close a big amount of hospitals, and replace them with several dozens of family doctors who are specialized in medical healthcare, village ambulatories must be renamed into the ambulatories of family medicine and every one of them should have a family doctor. All main qualified medical care should be transferred to TMA (territorial medical association), which will be located in the biggest district centers (one TMA for 3-4 districts) and regional centers.

According to the reform, the medical examination should be conducted by family doctors, whose functional duties are observing children from the first years of their life and adults, health improvement, vaccination, and educating people in leading a healthy way of life. It should be mentioned that the work hours of the family doctor are significantly longer than his/her actual abilities, and all of this is combined with their low wages. This means that medical examination, instead of being a symbol of prophylactic medicine, has become a great profanation which costs 6 billion. Doctors formally conducted medical examination. However, if the diseases had been detected, this would have not caused the treatment and provision of certain medicines due to lack of money in the state's budget.

Maybe it is necessary to implement laws on medical examination undergoing, which will set the more difficult conditions for citizens, who do not care about their health state, in relation to insurance, lending, employment, education and etc.

However, if there is no health and there are no funds for medical treatment, surgery or expensive effective medicine, than a person has only one way - to lie to the state, that they are perfectly healthy while buying medical certificates.

So, doctors believe that the plans of the $\mathrm{MOH}$ are impossible, from a legal point of view. For the majority of the population there are no labor 
obligations in relation to medical examination undergoing, just like it was in the USSR. Making people forcefully undergo medical examination is a very hard task to accomplish. The government hopes that family doctors will recommend their patients to undergo a medical examination. However, the institution of a family doctor is not developed enough in Ukraine.

One of the main problems of Ukrainian family medicine is financing one. In the primary care establishments only up to $30 \%$ of patients start and completely finish their treatment and only $50 \%$ in rural areas ${ }^{2}$.

The share weight of amounts for maintaining healthcare establishments, which provide first-aid medical-sanitary treatment, is less than $10 \%$ of the general amount of expenses on healthcare that, considering the poor level of material and technical support, is absolutely insufficient.

Staff provision is also an important problem of the family medicine in Ukraine. Although there is a rather high number of graduates, only a small amount of them remain to work in a medical field, which is mostly explained by low wages, the lack of social guarantees and the conditions for young professionals. We should also note that forced sending of young professionals to work in healthcare establishment does not bring any expected positive results. A significant rise of the outflow of paramedical professionals to neighboring countries is being observed, where the wages for similar work are much higher (in countries like Poland, Czech Republic, Russian Federation and Belarus).

The stuff provision problem is not only associated with training of family doctors, but also family nurses, which is the most specific part of the reform. First of all, there is a lack of training for family nurses in our educating establishments, and secondly, there are not proper advanced training courses for them.

Moreover, family medicine provides that every doctor must treat 1200 individuals, and nurses must treat 600 individuals each year. This means that for every family doctor there should be two family nurses, but that is not true. The main issue here is not in insufficient number, but in the fact that the organization of work in our clinics is the same as it was before- with an irrational split of work forces.

\footnotetext{
${ }^{2}$ Гришман Л.Семейный врач: миф или реальность? / Здоров'я України. - № 18. - Сентябрь. - 2008. C. 62 .
} 
Basic analysis can be conducted in the primary sanitary-medical treatment establishments (in ambulatories), namely: the analysis of blood, urine, the level of glucose in blood. If there is a necessity in a further, more detailed examination and consultation, the first-aid doctor (family doctor, therapeuist, pediatrician, and obstetrician-gynecologist) gives referrals to the medical establishment of the secondary level. The amount of needed examinations is determined by the patient's illness.

As we could see, medical examinations, conducted by a family doctor, have a miserable scope of examinations and a medial examination by the specialist is not provided. Although the family doctor is being defined as a super-doctor of a new formation, who knows both therapy and gynecology, pediatrics and neurology, ophthalmology, surgery and psychiatrics and other fields of medicine. However, in reality, he/she just turns into a paramedic of a general profile.

Often the examples of rural doctors are given to justify the positions of family doctors, rural doctors who worked at village areas in the $19^{\text {th }}$ century. At that time medicine used to be at another level of development and there were not any specific medical specializations.

Such a state as Ukraine cannot fully finance the healthcare industry; not any budget will be enough to fully cover it. We can completely forget about soviet-type medicine, which was funded from the state's money. And the family medicine, first of all, provides for a change in distribution of funds. We cannot take the way of financing highly specialized establishments (which are expensive), so it is necessary to change the approaches for providing medical treatment.

In international practice there are several types of family doctors' work. It is too early to decide how the Ukrainian family doctor is going to work. The essence is in the fact that the funds are being redistributed per each citizen with whom a doctor works, and not for an in-patient bed, like it was in the previous system ${ }^{3,4}$.

In practice this means that the doctor is interested in healing the patient, and so that the patient stays healthy for a long time (if the patient is not ill, the money is still distributed. Half of them are going to

3 Хвисюк О.М. Розвиток сімейної медицини і здоров'я населення // О.М.Хвисюк, А.Р.Короп, О.М. Зайцев // Проблеми сучасної медичної науки та освіти. - 2009.- № 4. - С.5-9.

${ }^{4}$ Проблемы организации диспансерного наблюдения детей сельской местности / Н.М. Коренев, Л.П. Булага, А.М. Коломиец [и др.] // Актуальні питання внутрішньої медицини в практиці сімейного лікаря: матеріали наук.-практ. конф. 3 міжнар. участю, 4-5 жовтня 2006 р., Харків / М-во охорони здоров’я України [та ін.]. - Х.: Харк. акад. післядипл. освіти, 2006. - С. 37-38. 
additional wages, and the other half goes for the family ambulatories equipment). In modern hospitals the doctor's wage depends on the amount of a number and time of patient's staying in the ward, which means that currently it is profitable for the doctor to treat their patient slowly and ineffectively.

The turnover of funds, allocated to every citizen, is a fund, which is either fully or partially being run by a family doctor. He/she can only direct them, but they do not actually belong to him/her. Theoretically, if he/she has already treated a patient, the allocated money is still in the fund. If the case requires specialized assistance, then it will be funded from the same fund. Here it is possible see the family doctor's interest not to refer a patient to a certain specialist, even if it is needed. For example, a salary of a family doctor varies from $1650 \mathrm{UAH}$ to $6500 \mathrm{UAH}$ and depends on the amount of money, which is left in the fund.

Maybe, it would be easier to go to see a doctor since a person would know where and from whom specifically it is possible to receive help. If some specific assistance is needed, this is a family doctors' care.

This is how the principle of stages will be conducted; 70-80\% of referrals will go under the competence of family doctors - the first-aid level. $20 \%$ of them are going to stationary hospitals, where they get help from specialists. This is the secondary level. $10 \%$ of them, who need treatment in institutions and clinics, are most likely patients with rare or severe complicated diseases - this is the third level of assistance.

And if the patients really want to get a certain specialists' assistance, they can obtain it even without a reference of a family doctor, but on a paid basis.

Vaccination is injection of antigenic material with the goal of asserting immunity to an illness, which will prevent infection and weaken its consequences.

According to the Annex to the Order № 48 of $\mathrm{MOH}$ of Ukraine on 03.02.2006 "On the procedures of conducting prophylactic vaccinations in Ukraine and the control of quality and circulation of medical immunebiological drugs" (hereinafter referred to as the № 48 Order of $\mathrm{MOH}$ ), the following vaccinations against certain illnesses are included to the schedule, made in such ages: tuberculosis - 3-7 days, 7 and 14 years; hepatitis $\mathrm{B}$ in the first day, the $1^{\text {st }}$ and $6^{\text {th }}$ month of life; diphtheria on the $3^{\text {rd }}, 4^{\text {th }}, 5^{\text {th }}, 18^{\text {th }}$ month, and then every 10 years; whooping cough $3,4,5$, 
18 month; tetanus $3,4,5,18$ months, $6,14,18$ years, then every 10 years; poliomyelitis inactivated (dead) vaccine: 3,4 month, oral (alive) vaccine: 5, 18 month, 6, 14, years; hemophilic infection 3, 4, 5, 17 month; measles 12 month, 6 years; rubella 12 month, 6 years, 15 years (for girls); parotiditis 12 month, 6 years, 15 years (for boys).

Mandatory vaccinations (although one could refuse from them, as we could see below) are only vaccinations consolidated in the Law of Ukraine "On Protection of Citizens from Infectious Diseases" (Article 12) and in the Law of Ukraine "On providing sanitary and epidemiological well-being of the population" (Article 27) against diphtheria, whooping cough, measles, poliomyelitis, tetanus and tuberculosis. As we could see, vaccinations against hepatitis $\mathrm{B}$, hemophilic infections, rubella and parotitis are not mandatory, although they are included in the vaccination calendar. Unfortunately, this fact is unknown to most of parents, which are being asserted in the hospitals that all of the vaccines included in the calendar are «mandatory». However, the illegality of including these vaccinations to the calendar is well-known in the $\mathrm{MOH}$ and the Verkhovna Rada of Ukraine: a good illustration of this is an attempt in June of 2007 to «drag in» a law this addition to the list of mandatory vaccinations, the vaccinations against Hepatitis $B$, hemophilic infection and rabies.

In the same order №48 $\mathrm{MOH}$ officially recognizes the possibility of two types of undesirable consequences of vaccinations: reactions (clinical and laboratory signs of unstable pathological functional changes in the organism, which appear because of the effects of vaccinations) and the complications ("long-lasting functional and morphological changes in the organism, which go beyond the limits of physiological fluctuations and result in major violations of health state").

Therefore, the Law of Ukraine "The Fundamentals of Ukrainian Law on Health Care" (Article 42) prohibits medical interference (the use of diagnostic methods, prophylactic or treatment, associated with the influence on the human organism), when it could harm the health of the patient. However, practice shows that this does not prevent vaccines from endangering the health of children and adults.

There are also contradictions to vaccinations. In the order № 48 of $\mathrm{MOH}$ it is repeatedly emphasized on the importance of the accounting of contraindication: "The vaccines are only allowed to be done if.... they 
meet the indications and contraindications about their injection". All newborn babies who do not have contraindications are obligated to have vaccinations. However, as we could previously see «all newborns» get vaccines from hepatitis and tuberculosis, according to the vaccination calendar, while they are in the maternity clinic, in the first days or even hours after being born, and among the contraindications, we could see the following ones in the same order:

- Severe complications from the previous dose in the form of anaphylactic shock;

- Allergies to any components of the vaccine;

- Epileptic seizure syndrome with convulsion twice a month and more often;

- Complicated reactions to previous vaccine injections;

- Tuberculosis infections;

It is clear that none of these diagnoses could be either confirmed, nor could it be disproved for a baby:

- The «previous doze» is absent in the baby, that is why no one could guarantee the absence of anaphylactic shock or any "complicated reaction" as a response to the vaccine;

- No baby is examined for a sign of an allergic reaction "to any component of the vaccine" (since the vaccine contain a lot of dangerous components, including such well-known allergens, as protein compounds, mercury, phenol, etc.);

- The presence of a newborn epileptic syndrome - the frequency of convulsions can not be predicted at birth;

- And, of course, none of the babies could be examined for tuberculosis infection.

Consequently, all of the contraindications mentioned above and "predictably" documented by $\mathrm{MOH}$, in relation to babies, can not be completely checked. However, even elder children, who have already received vaccinations, are not insured from more tragic consequences, because, for example, toxic substances, included in the vaccine, with regular injection, can show the so-called cumulative (accumulation) effect. This property of vaccines in the MOH documents is not shown in any way; such risk factor as a number of vaccines that have been already injected in a children, is not included in the contraindications. As a result 
the second, third or even the last of "mandatory" vaccinations could be fatal, although the previous ones were absolutely "normal".

In case the health state deterioration related to the vaccination, one should see a doctor, who is financially and administratively independent from the clinic that did the vaccination. Otherwise, the diagnosis may not be objective (which means that the treatment could not be adequate), just "not to spoil the reputation of the clinic".

The doctor is obligated to fully provide information about the possible negative consequences of vaccines in the full extent and timely, which means before the vaccinations are done. This is regulated by:

- The Civil Code of Ukraine (Article 302 "A natural person has the right to freely collect, store, use and disseminate information");

- The Law of Ukraine "The Fundamentals of Ukrainian Law on Health Care" (Article 6 "Every citizen of Ukraine has the right to.... be reliably and timely informed about the state of their health and the state of population's health, including the existing and possible factors of risks and their stage»; Article 39 "The doctor is obliged to inform the patient in a clear form the aim of conducting recommended treatment measures... And also the risks for the patient's life and health";

- The Law of Ukraine "On the Protection of Childhood" (Article 6 "...the state uses the measures to provide all layers of society, in particular parents and children, with the information about healthcare"

-The Law of Ukraine "On Information" (Article 5 "The main principles of informational relations are: the guarantee about the rights to be informed, openness, and the availability of the information, the fullness and the preciseness of the information"; Article 9 "All citizens of Ukraine have the right to information, which provides the possibility to freely access the information, necessary for them to realize their rights"; Article 29 "The access to open information is ensured by freely providing interested citizens with it", Article 30 "Information about medical services cannot be referred to.... confidential information");

- The Law of Ukraine "On Protection of Population from Infectious Diseases" (Article 12 "Medical employees, who conduct prophylactic vaccinations are obliged to provide objective information to individuals who undergo vaccination or to their legal representatives about the effectiveness of prophylactic vaccinations and what the possible post- 
vaccination complications are. Individuals from the age of 15 to 18 years undergo vaccination ... only after provision of objective information....");

- The Law of Ukraine "On protection of sanitary and epidemic wellbeing of the population" (Article 4 "Citizens have the right to objective and timely information about the existing and possible risk factors for their health state and their extant");

- The Constitution of Ukraine (Article 50 «Every citizen is guaranteed to have the rights to have free access to the information about the state of the environment, the quality of food products and household items. This kind of information cannot be confidential.");

- The Law of Ukraine "On Protection of Consumer Rights") (Article 41 "Consumers during the purchase or the use of products, sold at the territory of Ukraine, have the right to... necessary, accessible, accurate and timely information on the products"; Article 6 "The seller (the manufacturer, the executor) is obliged to provide information about this product."; Article 15 "The consumer has the right to be provided with necessary, accessible, reliable and in-time information about the product. The information should be provided to the consumer prior to the consumer buying the product or ordering work (services). Information about the products must include... information about the components that are harmful for the health and precautions regarding the use of individual products; a remark of existence in the components of genetically-modified components. Talking about the products, that may be life-threatening to the health of the consumer, the manufacturer (the executor, seller) is obliged to provide the consumer with the information about the products and possible consequences of their consuming (using)";

- The International Code of Medical Ethics ("The doctor must be absolutely honest with the patients");

- Convention for the Protection of Human Rights and the Dignity regarding the application of biology and medicine (Convection on human rights and biomedicine) - Article 5 "...a person is provided in advance with relevant information about the goals and the nature of intervention, as well as its consequences and risks";

- Convention on Children's Rights (Article 24 «State members... use measures on....the provision of information to all layers of society, in particular parents and children, regarding the health of children, hygiene, sanitation of the child's environment and the prevention of accidents. 
Vaccinations, as well as other procedures (such as the tuberculosis test, fluorography, blood analysis, etc), are types of medical aid that could be declined");

- The Civil Code of Ukraine (Article 284 "Granting medical aid to a natural person, who reached the age of 14 , could only be done with consent ....A natural person in full legal age ....has the right to decline from the treatment");

- Convention for the Protection of Human Rights and the Dignity regarding the application of biology and medicine (Convection on human rights and biomedicine)

- Article 5 "Any intervention in the field of health could only be done after an informed free-will consent of the relevant individual. The relevant individual could withdraw from his/her consent at any time without any obstacle"; Article 6 "According to the legislation, if a minor person is not legally capable to give his/her consent to medical intervention, it could only be carried out with the permission of their representative. Vaccinations are a method of prophylactic measures, which is quite risky";

- The Law of Ukraine "The Fundamentals of Ukrainian Law on Health Care» (Article 42 «Risky methods.... of prophylactic measures.... are considered appropriate, if they are....being used with the consent of a patient who is informed about their possible negative consequences"; Article 43 "The consent of an informed patient is necessary for the use of... prophylactic methods... Regarding the patient, who has not reached the age of 15 , medical intervention is carried out with the consent of his/her legal representatives"

The possibility of refusal from the injections of vaccines is directly enshrined in the law:

- The Law of Ukraine "On Protection of Population from Infectious Diseases" (Article 12 "Full-aged legally capable citizens get prophylactic vaccinations only with their consent... Individuals, who have not reached the age of $15 \ldots$..get vaccinated with the consent of their parents. Individuals of 15 to 18 years old get prophylactic vaccinations with their consent and with the consent of their parents...The information about...the refusal from prophylactic vaccinations are subject to statistical recording". If the person and (or) their legal representatives refuse from mandatory 
prophylactic vaccinations, a doctor has the right to take an appropriate written confirmation from them.

It is enough to leave the refusal in written form in your local hospital (or send it there as a recommended letter with a statement about of its delivery) in one copy, if a child is not attending kindergarten or school»;

- The Law of Ukraine "On Protection of Population from Infectious Diseases» (Article 12 "If the person and (or) his/her legal representatives refuse from mandatory prophylactic vaccination, the doctor has the right to take an appropriate written confirmation from them, and if they refuse to give such confirmation - to testify it by the act in the presence of witnesses.

If the refusal is made while attending a maternity hospital, a kindergarten or a school, then it is necessary to give a copy of the refusal with the acknowledgment to the administrator of the establishment, as well as to other persons, who can participate in the vaccination procedure: obstetrician, a school nurse, a teacher and others. A separate copy of the refusal is necessary to put in the child's school diary (with the ability to present it if required), and a child should be educated how to behave appropriately.

At the same time, medical staff of the clinic cannot demand the inclusion of additional points in the refusal of vaccinations: about the refusal of parents from treatment, about the parent's responsibility for the consequences of the illnesses and etc. The form of the refusal is not defined by law, and parents should not support such self-initiated activity of the clinic, because medical aid could be needed in situations not related to vaccinations.

Refusal from the acceptance of non-vaccinated children into the kindergarten or school is considered illegal. Even one of the Laws of Ukraine prohibits non-vaccinated children to attend children establishments": the Law of Ukraine "On Protection of Population from Infectious Diseases" (Article 15 «Children, not attended prophylactic vaccinations according to the vaccination calendar are prohibited to attend children establishments").

However, a number of other laws (and especially the Constitution, having the highest legal force - Article 8) establish the absolute right to education for every child: 
- The Constitution of Ukraine (Article 53 "Everyone has the right to education. Full comprehensive secondary education is compulsory");

- The decision of the Constitutional Court of Ukraine from 04.03.2003 № 5-rp/2004 ("The availability of education as a constitutional guarantee of the realization of the right to education... means, that no one could be refused in their right to education, and the state must create opportunities to exercise this right");

- The Law of Ukraine "On Protection of Childhood" (Article 19 "Every child has the right to education");

- The Law of Ukraine "On General Secondary Education" (Article 2 "...ensuring the rights of citizens for the accessibility of the general secondary education which should be absolutely free"; Article 6 "...To Ukrainian citizens independently... on...the convictions... or any other features the accessibility of the absolutely free general secondary education is provided...");

- The Law of Ukraine "On Pre-school Education" (Article 2 "...ensuring of the child's right to have accessible free pre-school education"; «Article 6 «...the accessibility for every citizen to educational services, given by pre-school education system...”);

- The Law of Ukraine "On Education" (Article 3 "Ukrainian citizens have the right to have free education in every state education establishments, regardless of...worldviews...health state and other circumstances»; Article 6 «Main principles of education in Ukraine are: the accessibility for every citizen of all forms and types of educational services provided by the state");

- The First Protocol of the Convection On Protection of Human Rights and Fundamental Freedoms (Article 2 "No one could be denied the right to education");

- Convention on the Rights of the Child (Article 28 «State Parties recognize the right of the child to education, and with a view to achieving this right progressively and on the basis of equal opportunity they shall, in particular....a) make primary education compulsory and available free to all);

- Universal declaration of human rights (Article 26 "Every person has the right to education. Primary education must be compulsory");

- International Covenant on economic, social and cultural rights (Article 13 «1. States, who participate in this Covenant, recognize the 
rights of every person to education. 2. a) primary education shall be compulsory, b) secondary education shall be open and accessible for all by taking necessary measures»);

- Convention on the fight against discrimination in education (Article 1 «1. ... the term "discrimination" includes any discrepancy, exclusion, restriction or advantage on the basis of...convictions... which has the goal or the consequences of destruction or violation of the equality of relations in education, and in particular: a) the closure of access to education of some grade or type to an individual or a group of individuals".)

In addition, a number of laws protect Ukrainian citizens from discrimination, connected to convictions or the health state;

- The Constitution of Ukraine (Article 24 "The citizens have equal constitutional rights and freedoms before the law. There cannot be privileges or restrictions associated with the features...convictions... or some others features");

- The Law of Ukraine "The Fundamentals of Ukrainian Law on Health Care" (Article 6 "Every citizen of Ukraine has the right to health protection, which provides... d) legal protection against any illegal forms of discrimination, associated with the health state");

- Convention for the Protection of Human Rights and Fundamental Freedoms (Article 14 (1) "The exercise of rights and freedoms shall be guaranteed without any discrimination or...convictions...or any other circumstances»);

- Protocol № 12 to the Convection for the Protection of Human Rights and Fundamental Freedoms (Article 1 "1. The implementation of any right stipulated by law is ensured without discrimination based on any feature, for example the feature.... convictions... or any other features. 2. No one could be discriminated by any of the state body based on any kind of feature, for example on such specified in the clause 1");

- Convention on the Rights of the Child (Article 2 "1. State Parties.... provide every... rights... without any discrimination, regardless of the health's state.... of the child. 2. State Parties... take all necessary measures to ensure the protection of child from any forms of discrimination.... based on... the beliefs or the opinions of the child, child's parents, legal guardians or any other family members";

- Convention for the Protection of Human Rights and Dignity with regard to the Application of Biology and Medicine (Convention on the 
Human Rights and Biomedicine) (Article 1 "The Parties to this Convection protect the dignity and the equality of all people and guarantee to each person - without any discrimination -respect for their inviolability - and other rights and fundamental freedoms with regard to the application of biology and medicine");

- The Universal Declaration of Human Rights (Article 19 "Every person has the right to freedom of their beliefs and their expression; this right includes the freedom to freely adhere to their convictions");

- The European Social Charter (Part 1 "11. Every person has the right to use any means which would help them to achieve the best possible health state")

So, how one can settle a child to kindergarten or school without vaccination?

- The procedure of accepting children into a kindergarten is established by a relevant Regulations "On the Pre-school Educational Establishment" and approved by the Cabinet of the Ministers of Ukraine on $12^{\text {th }}$ of March, 2003 № 305 (" 6 . The acceptance of children into the pre-school educational establishment is conducted by the administrator of the establishment during a calendar year based on the parents' application or the persons who act in their capacity, the medical certificate about the children's health state, and the certificate by the district doctor on the epidemiological environment as well as a birth certificate. 12. The expulsion of a child from a pre-school educational establishment of a public and communal ownership could be done.... based on the medical conclusion on the child's health state, which excludes the possibility of their further stay in a pre-school educational establishment of this type... The administration of the pre-school educational establishment is obliged to inform the parents or persons who act in their capacity about the expulsion of the child in a written form and at least 10 calendar days prior the expulsion. The expulsion from a pre-school educational establishment without reasons is strictly prohibited; 13. The procedure for the acceptance, expulsion and keeping of child's place in a pre-school establishment with a private form of ownership is determined by the founder (the owner). The procedure for the acceptance of children is established by law");

- The Law of Ukraine "On General Secondary Education" (Article 18 "The enrolment of pupils. 2. The enrolment of pupils to 
secondary educational establishment is conducted by the order of the director, issued on the basis of the application, with the presence of the standard medical certificate and accordingly the document about education (excluding first grade pupils)".

As we could see, in both cases, the head of the establishment is responsible for the child's enrolment to the children establishment. The immediate presence of vaccinations is not listed as a necessary condition of the child's enrolment. Such necessary condition is the availability of a medical certificate about the state of health, namely, whether the child is healthy or sick at the moment. It is absolutely obvious that the absence of vaccinations themselves does not mean that the child is sick. Practice shows, as a rule, that the head of the kindergarten/school will be totally satisfied with the conclusion in the medical certificate like this: "According to the child's health state, he or she is capable of attending kindergarten/school. This option is fully in compliance with the law, and this is what you must request from the clinic.

A letter is given to the clinic with the requirement to give a medical certificate for settlement a child to the kindergarten or the school. In case of the clinic's refusal to give such certificate a new letter (in an appropriate form) with the situation description and a copy of the refusal must be sent into the local prosecutor's office and to the public office of the President of Ukraine. In addition, you can simultaneously file a claim on violation of the constitutional right to education to the court. If the clinic insists that a non-vaccinated child cannot attend the group because of his or her health state, then one can require in the application to open a medical leave certificate for taking care about the child. In no case one should try to obtain a "fake" certificate. Such actions are considered as a crime, and in that way, the child will be registered as vaccinated in the certificate, which will not protect him or her from unplanned or planned vaccinations at the place of studying. Even if the parents warned the staff about the "individual schedule of vaccination", such child still can not avoid a "planned" vaccination.

The doctor has no right to inform the school, kindergarten, workplace or the neighbors of "refusing persons" about refusal from vaccinations. The presence or the absence of vaccinations refers to the information about the patient's health state, which means this is confidential medical information which cannot be disclosed: 
- The Civil Code of Ukraine (Article 286 " 1 . A natural person has the right to the secret of information about their health state, about the fact of referring to medical aid, diagnosis, as well as the information that they have obtained while attending a medical examination. 2 . It is illegal to require and submit the information about the diagnoses and methods of treating of the natural person at workplace or educational establishment. 3. A natural person is obliged to keep from disseminating information, mentioned in the first part of this article, which became known to him or her in connection with the performance of official duties or other sources");

- The Law of Ukraine "Fundamentals of Ukrainian Law on Health Care" (Article 40 "Medical staff and other persons who in connection with their professional or official duties obtained information about the illness, medical examination, check and its result, private and family life of the citizen, do not have the right to disclose such information, except situations provided by legal acts);

- The Law of Ukraine "On Information" (Article 46 "The information which belongs to the medical secret shall not be disclosed").

The consequences of positive Mantoux test (tuberculosis diagnostic) could be as follows:

- The Law of Ukraine "On the Fight against Tuberculosis Infection" (Article 1 "Tuberculosis diagnostic is a specific diagnostic test, which is done with tuberculin, to detect those who are infected with the tuberculosis micro-bacteria timely and those who are tuberculosis-ill; the persons infected with the tuberculosis bacteria are those who have a positive immune reaction to tuberculin").

Thus, a positive Mantoux test (which usually appears as "false positive" because of the allergic reaction to tuberculin, which will be found out later) proves that the person is infected. According to the law such measures will be immediately taken to a person:

- The Law of Ukraine "On the Fight against Tuberculosis Infection" (Article 11 "Chemo-prophylactic of tuberculosis applies to the persons, who are infected with micro-bacteria of tuberculosis and are under 18 years, in whom a positive reaction to tuberculin has been detected for the first time in their lives.. The persons, who are infected with the tuberculin micro-bacteria aged over 18 , can undergo chemo-prophylactic under the conditions of medical indications"). 
As we could see, such child will be immediately exposed to chemoprophylactic therapy without any additional medical examinations or indications (which is different from adults) as well as registered in tuberculosis-dispensary with mandatory regular $\mathrm{x}$-ray diagnostics and etc. This is why the rejection from the Mantu test from the start would be the most right action and the request for help of psychiatric only if there are problems with lungs or breathing organs. A person, who does not have the status of a tuberculosis-infected person, can freely reject the Mantu test as well as any other vaccinations or medical interventions.

The Refusal of the acceptance of children into the kindergarten or the school based on the absence of Mantoux test is illegal. Moreover, this is what is written in the law on vaccination and tuberculosis diagnostic:

- The Law of Ukraine "On the Protection of Population from Infectious Diseases" (Article 15 "Children, who have not received prophylactic vaccinations according to the calendar of vaccinations, are not allowed to attend children establishments");

- The Law of Ukraine "On the Fight against Illnesses and Tuberculosis" (Article 10 "The Registration and acceptance of children under 14 to educational, health-care and other children establishments is carried out according to the requirements of Article 15 of the Law of Ukraine "On the Protection of Population from Infectious Diseases".)

The results of tuberculin diagnostic and other types of tuberculosis diagnostic for children are given in the appropriate certificate of the health care establishment. However, Mantoux test is not a vaccination; it is an entirely different concept:

- The Order № 48 of $\mathrm{MOH}$ (““...In children, who are under the age of two month, vaccinations against tuberculosis are carried out without the previous Mantoux test....Vaccination is conducted if case of the negative results of the test....the Mantoux test is conducted after prophylactic vaccinations").

Therefore, Article 15 mentioned above can not be applied in that situation and Article 10 requires only the provision of a certificate from the clinic about the results of Mantoux test (for example, "not done") and about the absence of clinical signs of tuberculosis.

In addition, Article 10 can not be applied at all to children who are already attending a children establishment. For these children, the Procedure for carrying out compulsory prophylactic examinations of 
particular categories of the population to detect tuberculosis can be applied (approved by the Cabinet of Ministers of Ukraine № 143 on $15^{\text {th }}$ February, 2006. "4. During compulsory medical examination such diagnosis methods are used: - tuberculosis diagnostic - for children under the age of 15 ").

In this case, we could not find information in laws about possible sanctions regarding children, which have not undergone medical examination in full. At least in the event of threat of such sanctions, the parents of the children must require detailed explanations with the reference to different laws (but not to the Order of the Ministry, the State Service on Safety of Food Products, and etc.

Does the lack of vaccinations apply restrictions to the choice of professions now or in the future? On the one hand, it is obvious that the legislation of Ukraine clearly states about the professions which require compulsory additional vaccinations (excluding the calendar ones):

- The Law of Ukraine "On the Protection of Population against Infectious Diseases" (Article 12 "Prophylactic vaccinations against diphtheria, whooping cough, measles, poliomyelitis, tetanus, tuberculosis are compulsory and included in the calendar of vaccinations. Employees of certain professions, industries and organizations whose activities may lead to the infection of these employees and (or) the spread of infectious diseases, are subject to compulsory preventive vaccination against other relevant infectious diseases. In case of refusal or evasion from compulsory preventive vaccinations under the procedure established by law, these employees are suspended from performing the specified types of work. The list of professions, industries and organizations whose employees are subject to compulsory preventive vaccination against other relevant infectious diseases is established by the Cabinet of Ministers of Ukraine").

On the other hand, there are no government regulations with such list of professions concerning vaccination. There is a list concerning compulsory medical examinations approved by the Resolution of the Cabinet of Ministers of Ukraine on 23d May, 2001 № 559 («The list of professions, industries and organizations whose employees are subject to compulsory prophylactic medical examinations") and the relevant Order of $\mathrm{MOH}$ about procedures conducted at such examinations (the Order of the Ministry of Health of Ukraine on 23.07.2002 № 280 (z0639-02) "The list of necessary examinations of special doctors, types of clinical, 
laboratory and other research necessary for carrying out compulsory examinations, and the regularity of their conduct". However, both these documents do not mention vaccinations. The list of such professions is in the Order of the Ministry of Health № 48 (in the section "Recommended vaccinations"), but the Order of the Ministry of Health cannot be equal to the Resolution of the Cabinet of Ministers.

In Ukraine, neither material compensation for victims of postvaccination complications nor temporary restrictions on the right to education are directly provided by in the Law "On the Protection of Population against Infectious Diseases". However, compensation for damage to health (which is any complication from vaccination) is provided by other laws of Ukraine and ratified international documents:

- The Law of Ukraine "On Fundamentals of Ukrainian Law on Health Care" (Article 6 "Every citizen of Ukraine has the right to health care, which provides: i) compensation for damage caused to health"; Article 8 "In case of violation of legitimate rights and interests of citizens in the field of health care, the relevant state, public or other bodies, enterprises, institutions and organizations, their officials and citizens are obliged to take measures for ... compensation for the damage caused");

Convention on the Protection of Human Rights and Dignity of the Human Being on the Application of Biology and Medicine (the Convention on Human Rights and Biomedicine) (Article 24 "A person who was unlawfully injured as a result of the interference has the right to a fair reimbursement in accordance with the requirements and procedures established by law").

Therefore, the right of Ukrainian citizens to prophylactic measures has received a new representation, which is, in fact, a simplification, costreduction and decrease in the level of examination and illness detection.

\section{REFERENCES:}

1. Гришман Л.Семейный врач: миф или реальность? / Здоров'я України. - № 18. - Сентябрь. - 2008. - С. 62.

2.Державне управління охороною здоров'я в Україні: генеза i перспективи розвитку : Монографія / О. В. Клименко, О. Я. Андрієнко, А. П. Казмірчук Я. Ф. Радиш, О. Я. Сорока, М. І. Бадюк, І. А. Данильчук, В. О. Жаховський, Р. Ф.Камалов // [кол. авт.; упоряд. проф. Я. Ф.Радиш, передм. Т. Д. Бахтеєвої; за заг. ред. 
проф. М. М. Білинської, проф. Я. Ф. Радиша]. - К. : НАДУ, 2013. 424 с. - Авторські с. 45-62, 288-293.

3. Дорофеев М. А. Совершенствование диспансеризации работающего населения в условиях модернизации здравоохранения. Дисс. канд. мед.н. - М., 2010. - С. 168.

4. КлименкоO. В. Right To Patient's Life / O. В. Клименко // The pharma innovation - journal. - Vol. 2.-№ 10. - 2013. - P. 53-57.

5. Клименко О. В. Реформирование системы здравоохранения в Украине / О. В. Клименко // Оралдын гылым жаршысы / Cер. : Эк. науки. Гос. упр. - Казахстан. - 2013. - № 30 (78). - С. 29-35.

6. Клименко О. В. Диспансеризация : памятник профилактической медицине в Украине / О. В. Клименко // Вестник государственного и муниципального права. - М. :- 2014.- № 1.C. $180-185$.

7. Клименко О. В. Законодавство в сфері охорони здоров'я : перспективи розвитку / О. В. Клименко // Економіка та держава. 2012. - № 5. - C. 128-131.

8. Клименко О. В. Державне регулювання медичної діяльності у сучасному суспільстві : Монографія / О. В. Клименко. - К. : Видавництво “Логос", 2013. - 368 с.

9. Проблемы организации диспансерного наблюдения детей сельской местности / Н.М. Коренев, Л.П. Булага, А.М. Коломиец [и др.] // Актуальні питання внутрішньої медицини в практиці сімейного лікаря: матеріали наук.-практ. конф. 3 міжнар. участю, 45 жовтня 2006 р., Харків / М-во охорони здоров'я України [та ін.]. Х.: Харк. акад. післядипл. освіти, 2006. - С. 37-38.

10. Хвисюк О.М. Розвиток сімейної медицини і здоров'я населення // О.М. Хвисюк, А.Р. Короп, О.М. Зайцев // Проблеми сучасної медичної науки та освіти. - 2009.- № 4. - С. 5-9.

\section{Information about the author:} Klimenko O. V.

Doctor of Sciences in Public Administration, Assistant Professor, Head of the Department of Constitutional and International Law of the V. I. Vernadsky Taurida National University 